DOI: https://doi.org/10.32839/2304-5809/2020-12-88-29

УДК 657.1

Кудлаєва Н.В., Андрицька B.I.

Чернівецький національний університет імені Юрія Федьковича

\title{
ФОРМУВАННЯ ОБЛІКОВО-АНАЛІТИЧНОГО ЗАБЕЗПЕЧЕННЯ УПРАВЛІННЯ ЗАПАСАМИ
}

\begin{abstract}
Анотація. У статті розглянуто місце обліково-аналітичного забезпечення управління запасами в обліково-аналітичній системі суб’єкта господарювання та у загальній системі управління. Визначено цілі, мету та основні завдання формування обліково-аналітичного забезпечення управління запасами. Охарактеризовано підходи щодо формування обліково-аналітичного забезпечення управління запасами, окреслено напрями його удосконалення. Уточнено визначення обліково-аналітичного забезпечення як повністю або частково децентралізованої системи, що відповідає цілям управління, спостереження, збору, ідентифікації, реестрації, узагальнення, обробки, контролю та аналізу всіх видів інформації, заснованої на перевагах сучасних інформаційних технологій і використовуваної для вироблення, обгрунтування і прийняття управлінських рішень.
\end{abstract}

Ключові слова: запаси, обліково-аналітичне забезпечення, управління запасами.

Kudlaieva Nataliia, Andrytska Viktoriia Yuriy Fedkovych Chernivtsi National University

\section{FORMATION OF ACCOUNTING AND ANALYTICAL SUPPORT OF INVENTORY MANAGEMENT}

Summary. In modern conditions of economic development, the efficiency of the enterprise depends very much on the quality of material support of the production process. The complexity of inventory management of the enterprise is associated with certain contradictions: in the presence of many factors that necessitate the creation of inventories (risk of failure of the production program due to late replenishment, possible fluctuations in production, the presence of costs depending on the frequency of replenishment), forced to bear large costs for their maintenance (storage costs, insurance, etc.). Therefore, any company faces the problem of accounting and analytical evaluation for effective inventory management, the solution of which can increase the efficiency of the entire enterprise. In domestic scientific research, comprehensive approaches to inventory management of business entities in the context of improving accounting and analytical support are not sufficiently disclosed. The purpose of the study is to substantiate approaches to the formation of accounting and analytical support of inventory management; identifying areas for improvement of accounting and analytical support of inventory management through analysis of scientific sources and existing practices. The article considers the place of accounting and analytical support of inventory management in the accounting and analytical system of the entity and in the general management system. The purposes, the purpose and the basic tasks of formation of the accounting and analytical maintenance of management of stocks are defined. Approaches to the formation of accounting and analytical support of inventory management are described, the directions of its improvement are outlined. The definition of accounting and analytical support as a fully or partially decentralized system that meets the objectives of management, monitoring, collection, identification, registration, generalization, processing, control and analysis of all types of information based on the benefits of modern information technology and used to develop, justify and making management decisions.

Keywords: inventories, accounting and analytical support, inventory management.

$\Pi$ остановка проблеми. У сучасних умовах розвитку економіки ефективність функціонування підприемства дуже сильно залежить від якості матеріального забезпечення виробничого процесу. Постає питання про формування повної і достовірної інформації про запаси (ї наявність, рух, використання), також якісної організації внутрішнього контролю за їх збереженням. Складність управління запасами підприемства пов'язана 3 наявністю певних протиріч: при наявності безлічі фракторів, які обумовлюють необхідність створення запасів (ризик зриву виконання виробничої програми через несвоєчасне поповнення запасів, можливі коливання обсягів виробництва, наявність витрат, що залежать від частоти поповнення запасів), підприємство змушене нести великі витрати на їх утримання (витрати на зберігання, страхування та т.д.). Тому перед будь-яким підприємством стоїть проблема обліково-аналітичної оцінки 3 метою ефрективного управління запасами, рішення якої дозволяє підвищити едективність діяльності всього підприемства.

Аналіз останніх досліджень і публікацій. Питання обліково-аналітичного забезпечення управління запасами підприемства отримали широкий розвиток в вітчизняній і зарубіжній літературі. Зокрема, значний внесок в розробку рекомендацій з обліку та аналізу запасів внесли такі дослідники, як: Р.Ф. Бруханський, А.М. Ганжинський, O.I. Гандзевич, Т.А. Шпатиковська, Л.I. Лежненко, О.І. Ломова, М.О. Неродюк, О.О. Осадча, Д.О. Постернак, М.Б. Тхагапко, О.Е. Халяпіна, Л.Р. Воляк, А.С. Харсун та ін.

Виділення невирішених раніше частин загальної проблеми. У вітчизняних наукових дослідженнях недостатньо розкриті комплексні підходи до управління запасами суб'єктів господарювання в контексті удосконалення обліковоаналітичного забезпечення.

Мета статті. На основі аналізу наукових джерел та існуючої практики обгрунтувати під- 
ходи до формування обліково-аналітичного забезпечення управління запасами; визначити напрями удосконалення обліково-аналітичного забезпечення управління запасами

Виклад основного матеріалу. Для того щоб діяльність підприємства була ефективною, необхідною умовою є створення обліково-аналітичного забезпечення, яке повинно враховувати особливості бізнес-процесів, що існують в галузі, в якій здійснюе діяльність субєкт господарювання.

Обліково-аналітична система є складовою частиною загальної системи управління, що базується на даних бухгалтерського обліку, суть якої полягає в поєднанні облікових і аналітичних операцій в єдиний процес, проведенні своєчасного мікроаналізу, безперервності цього процесу і використанні його результатів в ході розробки рекомендацій.

В цілому, обліково-аналітичну систему можна описати як упорядковану сукупність облікових, аудиторських, а також аналітичних процедур, при взаємодії яких зовнішні і внутрішні користувачі отримують інформацію необхідну для прийняття вірних, оперативних управлінських рішень. Обліково-аналітична система складається 3 декількох компонентів: обліково-аналітичного забезпечення та обліково-аналітичної інформації. Існує безліч різних підходів до тлумачення поняття обліково-аналітичного забезпечення.

Дослідник Р Ф. Бруханський розкриває поняття обліково-аналітичного забезпечення 3 точки зору системи, що «утворюеться в результаті формування індормації, джерелами якої є облікові і звітні дані бухгалтерського та інших видів обліку» [1, с. 109].

На думку авторів М.Б. Тхагапсо і О.Е. Халяпіна, «обліково-аналітичне забезпечення - це розтягнутий у часі безперервний процес формування і обробки інформації, результатом якого $\epsilon$ представлення даних в такому вигляді, щоб на їх основі можна було прийняти обгрунтоване i едрективне управлінське рішення» [8, с. 201].

Також існуе думка, що описуе обліково-аналітичне забезпечення як «сукупність елементів ресурсного забезпечення обліково-аналітичної системи (процедури, інструменти, методи), що забезпечуе обліково-аналітичне супроводження процесу прийняття управлінських рішень» [5, с. 345].

Аналізуючи точки зору різних дослідників на поняття обліково-аналітичного забезпечення, вважаємо, що його можна охарактеризувати як впорядковану, самостійну, повністю або частково децентралізовану систему, що відповідає цілям управління, спостереження, збору, ідентифрікації, реєстрації, узагальнення, обробки, контролю та аналізу всіх видів інформації, заснованої на перевагах сучасних інфрормаційних технологій i використовуваної для вироблення, обгрунтування і прийняття управлінських рішень.

Обліково-аналітичне забезпечення запасів входить в загальну систему обліково-аналітичного забезпечення управління господарюючим суб'єктом і займає в ній одну з найбільш значущих позицій. Таку високу значимість даної підсистеми можна пояснити тим, що запаси відіграють важливу роль у господарській діяльності будь-якого промислового підприемства, так як вони займають велику частку в його оборотному капіталі (табл. 1) і є основою і необхідною умовою виконання програм 3 випуску та реалізації продукції.

Отже, статистичні дані суб'єктів господарювання України свідчать, що запаси впродовж останніх років становлять близько 18-23\% у складі оборотних активів (табл. 1), що є важливим фрактором впливу їх діяльність, так як належний стан та ефрективне використання запасів забезпечуе безперебійність і ритмічність господарської діяльності підприемств, яке, в свою чергу, позитивно впливає на показники фінансового стану, що у подальшому сприятиме прийняттю обгрунтованих управлінських рішень, пов'язаних із запасами.

Обліково-аналітичне забезпечення запасів підприємства повинно відповідати його основним цілями. До таких цілей відносяться: збільшення рентабельності, зростання фрінансової стійкості, а також інвестищійної привабливості. Досягнення цих цілей здійснюеться за рахунок забезпечення системи управління запасами релевантною інформацією, яка розкриває реальний механізм процесів забезпечення матеріалами та їх споживання; визначення слабких ділянок діяльності та своєчасної нейтралізації негативних фракторів в області запасів.

Метою обліково-аналітичного забезпечення запасів підприємств є підвищення надійності матеріального забезпечення за допомогою раціональної компенсації відхилень, що виникають в процесі виконання планів постачання і планів виробництва продукції. Основні завдання обліково-аналітичного забезпечення запасів на підприемствах узагальнені на рис. 1.

Обліково-аналітичне забезпечення запасів суб’єкта господарювання має виконувати інфрормаційно-облікову, аналітичну та контрольну фрункщії 3 метою прийняття едрективних рішень на всіх рів-

Динаміка запасів на підприемствах України за 2015-2017 pр.

Таблиця 1

\begin{tabular}{|c|c|c|c|c|}
\hline \multirow{2}{*}{ Показник } & Звітний період & $\begin{array}{c}\text { Наявність запасів } \\
\text { на 31 грудня, } \\
\text { млн. грн. }\end{array}$ & $\begin{array}{c}\text { Наявність } \\
\text { оборотних активів } \\
\text { на 31 грудня, } \\
\text { млн. грн. }\end{array}$ & $\begin{array}{c}\text { Питома } \\
\text { вага запасів } \\
\text { в оборотних } \\
\text { активах, \% }\end{array}$ \\
\hline \multirow{2}{1}{} & $\mathbf{2}$ & $\mathbf{3}$ & $\mathbf{4}$ & $\mathbf{5}$ \\
\hline \multirow{2}{*}{$\begin{array}{c}\text { Разом по всіх видах } \\
\text { діяльності }\end{array}$} & 2015 & 850835,4 & 4108602,7 & 20,7 \\
\cline { 2 - 5 } & 2016 & 1046468,0 & 5772816,5 & 18,1 \\
\hline \multirow{3}{*}{ Промисловість } & 2017 & 1294619,9 & 5650817,4 & 22,9 \\
\cline { 2 - 5 } & 2015 & 289901,2 & 1201590,5 & 24,1 \\
\cline { 2 - 5 } & 2016 & 349754,1 & 1516831,9 & 23,1 \\
\hline
\end{tabular}

Джерело: розроблено авторами за даними [6] 


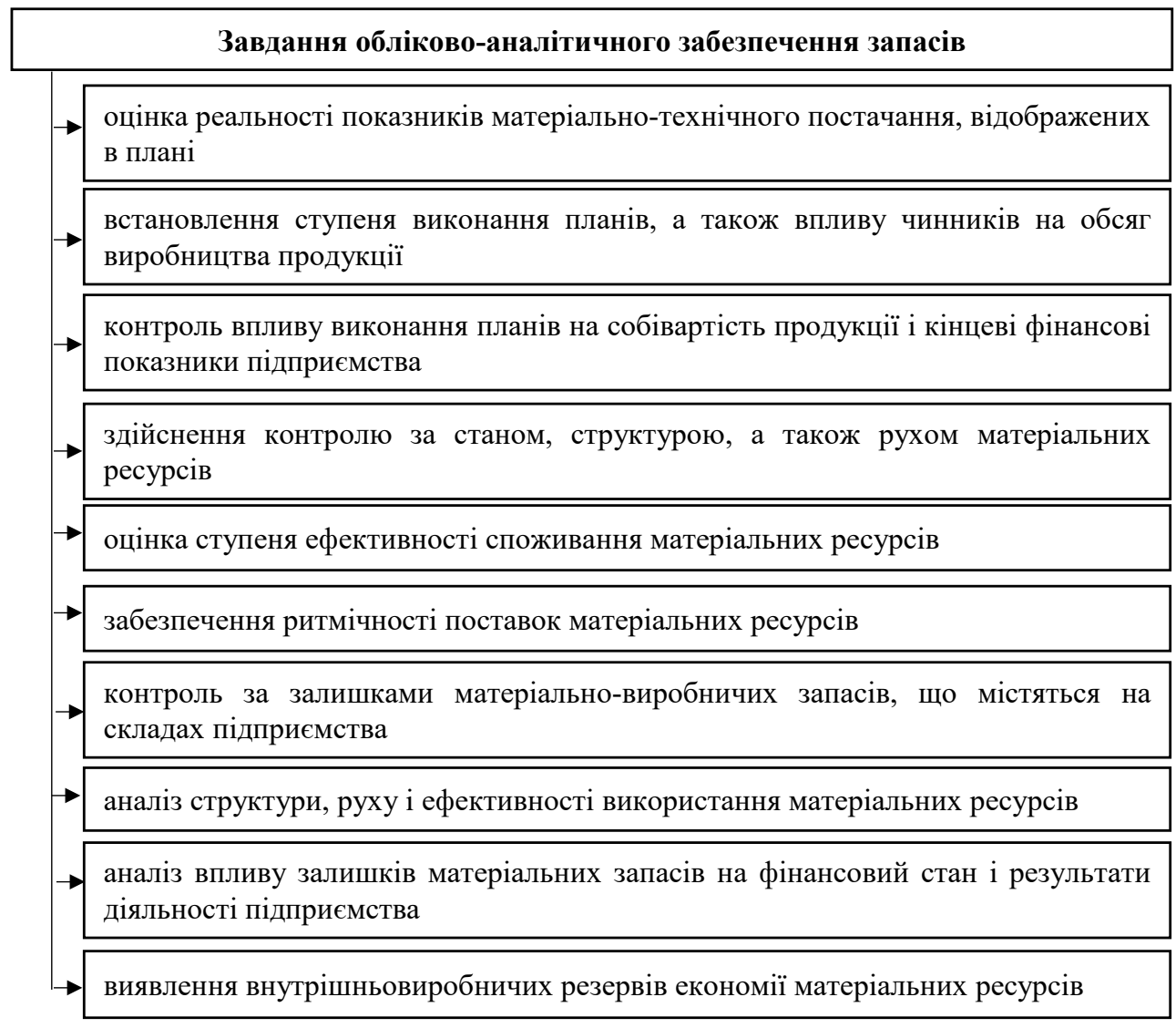

Рис. 1. Завдання обліково-аналітичного забезпечення запасів

нях управління. У сукупності заходів по реалізаціі обліково-аналітичного забезпечення запасів на підприємстві, важливе значення приділяеться форомуванню повної та достовірної інформації про наявність, рух, оцінку матеріальних цінностей, а також організащї внутрішньогосподарського контролю.

У даних умовах методично зв'язуючою ланкою при фонкщіонуванні обліково-аналітичного забезпечення запасів виступає облік. Основою облікової підсистеми управлінсько-аналітичного забезпечення є облікова інфрормація, яка представлена у вигляді первинної та звітної інформації.

Первинна індормащія $є$ базою для всіх видів обліку - фрінансового, управлінського і податкового. Носіями цього виду інформації виступають, в більшості випадків, первинні документи, в якості яких можуть застосовуватися уніфріковані фрорми або форми, які були розроблені підприємством в самостійному порядку. Звітна інформація, з одного боку, є вихідною в обліковій підсистемі, а з іншого боку, вона виступає в якості вхідної інформації в аналітичній підсистемі підприемства.

Бухгалтерський облік характеризується як центральна складова облікової підсистеми обліковоаналітичного забезпечення запасів. На базі бухгалтерського обліку формуеться і організовуеться аналітична діяльність 3 метою прийняття обгрунтованих рішень з управління матеріально-виробничими запасами, при щому, в області організащії безперервного аналізу досягаеться підвищення його оперативності та дієвості, з тієї причини, що аналіз безпосередньо слідуе за бухгалтерським обліком, а також виконуеться в процесі ведення dpiнансового та управлінського обліку.
Автори Л.І. Лежненко, О.I. Ломова до напрямів удосконалення системи управління запасами відносять «удосконалення аналітичного обліку виробничих запасів підприемства, враховуючи особливості його основної діяльності, що забезпечить: отримання більш точної та детальної інформації про наявність та рух виробничих запасів; здійснення чіткого та розгорнутого аналізу обсягів запасів на підприемстві, який надає змогу зробити висновки про збільшення рентабельності підприємства та прискорення обігу вкладеного капіталу: надання керівникам підприемства інформації щодо структури запасів, обсягів їх виробництва та реалізації для прийняття відповідних управлінських рішень» [4, с. 122].

Поряд 3 цим, підсистема аналітичного забезпечення управління матеріально-виробничими запасами стає постійно діючим фрактором підвищення едрективності їх використання, що обумовлено тим фрактом, що аналітична система забезпечує якісну і кількісну оцінку змін, які відбуваються в керованому об'єкті і, тим самим, дозволяе своєчасно помітити сприятливі і негативні явища і процеси.

Облік запасів повинен, в першу чергу, забезпечувати контроль за оперативністю постачання, коректністю складських залишків, виявляти невраховані матеріали, а також стежити за правильністю та обгрунтованістю використання ресурсів i, що найбільш важливо, своєчасно фрормувати інформацію, необхідну для цілей управління підприемством.

На думку О. Постернак, «для правильної організації обліку запасів на підприемстві перш за все необхідно дати відповідь на ряд запитань, удосконалення системи автоматизапії обліково-аналі- 
тичних робіт в управлінні виробничими запасами та обгрунтування ращіональних методів проведення інвентаризації виробничих запасів, узгодження механізмів бухгалтерського і податкового обліку виробничих запасів, обгрунтування системи обліку матеріальних витрат на освоєння нової техніки i технології виробництва, чітка організація обліково-контрольних процедур руху запасів підприємств (застосування прийомів обліку за центрами відповідальності заходів контролю та оперативного регулювання процесів утворення запасів)» [7].

Автори А.С. Харсун, Л.Р. Воляк стверджують, що необхідними передумовами правильної організації обліково-аналітичного забезпечення управління запасами є: «раціональна організація складського господарства; розробка номенклатури запасів; наявність інструкції 3 обліку виробничих запасів; правильна угруповання (класифікація) запасів; розробка норм витрачання запасів» [9].

Гадзевич O.I., Шпатиковська Т.А. відмічають, що "ращіональними напрямками вдосконалення обліково-аналітичних процесів щодо впровадження запасів будуть: широке застосування нових програм по автоматизації обліку; забезпечення суворого порядку приймання, зберігання та витрат сировини та матеріалів; ефективний контроль норм та витрат запасів; удосконалення форм документів обліку запасів» [3, с. 345].

Вище вказані заходи значно полегшать роботу обліково-аналітичним працівникам підприемств, зменшать ймовірність виникнення помилок, розбіжностей при веденні бухгалтерського обліку та здійсненні аналізу їх використання.

Висновки і пропозиції. Отже, система обліково-аналітичного забезпечення управління являе собою складний багаторівневий механізм, який об'єднує якісно неоднорідні складові. На основі поєднання облікової інформащії з виконанням додаткових аналітичних процедур забезпечуеться достовірна ощінка виробничих запасів що е основою ефрективного управління ними. Раціональне організаційно-аналітичне забезпечення управління виробничими запасами дозволить не тільки зменшити втрати від утримання надлишкових запасів, а й дасть можливість вивільнити значну частину коштів, що суттево покращить вартісно-оріентоване управління підприемством. Грамотно сорормована система обліково-аналітичного забезпечення запасів на підприемстві буде сприяти прийняттю едективних управлінських рішень щодо їх використання та підвищення контролю над ними, що сприятливо позначиться на економічних показниках діяльності підприемства.

\section{Список літератури:}

1. Бруханський Р.Ф. Модернізація обліково-інформаційного забезпечення стратегічного менеджменту сільськогосподарських підприемств : Матеріали колективної монографії у 2 т. / за ред. П.Й. Атамас [Сучасний бухгалтерський облік, аналіз і аудит: галузевий аспект, 1 т.]. Дніпропетровськ : «Герда», 2013. С. 21-34.

2. Гаджинский А.М. Управление запасами в логистике. Справочник экономиста. 2008. № 2. С. 98-104.

3. Гадзевич O.I., Шпатиковська Т.А. Обліково-аналітичне забезпечення виробничих запасів на сільськогосподарських підприемствах. Еконоліка і суспільство. 2016. № 6. С. 344-348.

4. Лежненко Л.I., Ломова О.І. Теоретичні аспекти удосконалення аналітичного обліку виробничих запасів. Молодий вчений. 2014. № 5(08). С. 122-126.

5. Неродюк М.О. Основні аспекти організації обліково-аналітичного забезпечення управління запасами підприемства. URL: https://conf.ztu.edu.ua/wp-content/uploads/2019/12/149.pdf (дата звернення: 30.11.2020).

6. Офіційний сайт Державної служби статистики. URL: www.ukrstat.gov.ua (дата звернення: 01.12.2020).

7. Постернак Д.О. Обліково-аналітичне забезпечення управління виробничими запасами. URL: http://ir.znau.edu.ua/bitstream/123456789/7957/1/PIOPF_2017_104-107.pdf (дата звернення: 30.11.2020).

8. Тхагапсо М.Б., Халяпина О.Е. Роль учетно-аналитического обеспечения в управлении предприятием. Вестник АГУ. 2015. № 3(165). С. 200-207.

9. Харсун А.С., Воляк Л.Р. Особенности учетно-аналитического обеспечения управления производственными запасами на сельскохозяйственных предприятиях. URL: https://cyberleninka.ru/article/n/osobennostiuchetno-analiticheskogo-obespecheniya-upravleniya-proizvodstvennymi-zapasami-na-selskohozyaystvennyhpredpriyatiyah (дата звернення: 30.11.2020).

\section{References:}

1. Brukhanskyy R.F. (2013) Modernizatsiya oblikovo-informatsiynoho zabezpechennya stratehichnoho menedzhmentu silskohospodarskykh pidpryyemstv [Modernization of accounting and strategic management information support farm]. Suchasnyy bukhhalterskyy oblik, analiz i audyt: haluzevyy aspekt [Modern accounting, analysis and audit, sectoral dimension]. Atamas P.Y. (Ed.). Dnepropetrovsk: «Herda». (in Ukrainian)

2. Gadzhynskyj A.M. (2008) Upravlenye zapasamy v logystyke. Spravochnyk ekonomysta, vol. 2, pp. 98-104.

3. Ghadzevych O.I., Shpatykovsjka T.A. (2016) Accounting and analytical support of production stocks at agricultural enterprises. Ekonomika $i$ suspiljstvo, no. 6, pp. 344-388.

4. Lezhnenko L.I., Lomova O.I. (2014) "Theoretical aspects of improvement of analytical accounting of production reserves". Young Scientist, no. 5(08), pp. 122-126.

5. Nerodyuk M.O. (2019) Osnovni aspekty organizaciyi oblikovo-analitychnogo zabezpechennya upravlinnya zapasamy pidpryyemstva. Available at: https://conf.ztu.edu.ua/wp-content/uploads/2019/12/149.pdf (accessed 30 November 2020).

6. Oficijnyj sajt Derzhavnoyi sluzhby statystyky. Available at: www.ukrstat.gov.ua (accessed 01 December 2020).

7. Posternak D.O. (2017) Oblikovo-analitychne zabezpechennya upravlinnya vyrobnychymy zapasamy. Available at: http://ir.znau.edu.ua/bitstream/123456789/7957/1/PIOPF_2017_104-107.pdf (accessed 30 November 2020).

8. Txagapso M.B., Xalyapyna O.E. (2015) Rol uchetno-analytycheskogo obespechenyya v upravlenyy predpryyatyem. Vestnyk AGU, no. 3(165), pp. 200-207.

9. Xarsun A.S., Volyak L.R. Osobennosty uchetno-analytycheskogo obespechenyya upravlenyya proyzvodstvennыmy zapasamy na selskoxozyajstvennux predpryyatyyax. Available at: https://cyberleninka.ru/article/n/osobennostiuchetno-analiticheskogo-obespecheniya-upravleniya-proizvodstvennymi-zapasami-na-selskohozyaystvennyhpredpriyatiyah (accessed 30 November 2020). 